\author{
Stanisław Nowosielski*
}

\title{
CONTROLLINGOWA KONCEPCJA ZARZĄDZANIA MALYM PRZEDSIĘBIORSTWEM. PODSTAWY KONSTRUOWANIA
}

\section{WPROWADZENIE}

Z badań i obserwacji wielu małych przedsiębiorstw krajowych wynika, że zarządzanie nimi jest jeszcze w dużym stopniu raczej „sztuką”, działaniem na zasadzie prób i błędów ${ }^{1}$. Zarządzanie oparte o intuicję, na tzw. wyczucie, charakterystyczne w początkowej fazie funkcjonowania firmy, $\mathrm{z}$ upływem czasu już nie wystarcza, a sam talent organizatorski właściciela i kwalifikacje zatrudnionych tam pracowników (menedżerów) nie są gwarancją sprawnego kierowania firmą. Wraz ze wzrostem firmy, szczególnie w warunkach dynamicznie zachodzących zmian w otoczeniu, rosnącej konkurencyjności, okazuje się, że bez solidniejszych podstaw wiedzy o zarządzaniu, niemożliwe jest długookresowe i w miarę spokojne jej funkcjonowanie. Pojawiają się różnego rodzaju perturbacje, zarówno w wymiarze rynkowym (np. utrata klientów), jak i finansowym (np. charakterystyczna dla małych firm długotrwała utrata płynności finansowej). Prowadzi to z reguły do poważnych kryzysów, a w konsekwencji również upadłości przedsiębiorstwa. Aby nie dopuścić do takich sytuacji nie wystarczy tylko aby właściciel małej firmy i zatrudnieni tam pracownicy pozyskiwali (,odnawiali”, poszerzali) wiedzę z zakresu zarządzania, ale należy także stale wspierać (wspomagać) zarządzanie, a w wielu wypadkach profesjonalizować procesy informacyjno-decyzyjne zarządzania. $\mathrm{Z}$ pomocą kierownictwu małych ${ }^{2}$

${ }^{*}$ Prof. zw. dr hab. inż., Uniwersytet Ekonomiczny we Wrocławiu.

1 Z. Mikołajczyk, K. Zi mniewicz, Zarzqdzanie małym przedsiębiorstwem, [w:] B. P i a s e cki (red.), Ekonomika i zarzq̨dzanie mała firma, PWN, Warszawa-Łódż 2001, s. 178.

${ }^{2} \mathrm{~W}$ literaturze przedmiotu pojęcie ,,małe przedsiębiorstwo” jest używane zwykle w połączeniu ze średnim przedsiębiorstwem, do oznaczania pewnej jednorodnej grupy przedsiębiorstwa (MSP), charakteryzującej się określoną specyfiką. Jednak specyfika i skala problemów związana z przedsiębiorstwem małym, nie zawsze jest identyczna $\mathrm{z}$ tą, która jest charakterystyczna dla przedsiębiorstwa jednoosobowego. Mikro przedsiębiorstwo pod wieloma ważnymi względami zupełnie nie przystaje do firmy małej w jej górnym przedziale wielkości (49 osób). 
przedsiębiorstw może przyjść controlling, traktowany jako koncepcja wspomagająca zarządzanie przedsiębiorstwem. O tym, że controlling jest narzędziem niezbędnym do prawidłowego funkcjonowania, przekonuje się coraz więcej przedsiębiorstw. W ostatnich latach obserwuje się duże zainteresowanie controllingiem wśród zarządzających małymi firmami. Najczęściej zainteresowanie to okazują ich właściciele, będący głównymi decydentami takich przedsiębiorstw. Wydaje się to oczywistym zachowaniem: wykorzystując swój kapitał chcą osiągnąć określony zwrot $\mathrm{z}$ inwestycji. Pojawia się jednak zasadniczy problem: w jaki sposób zbudować controlling, aby spełniał on swe zadania, a jednocześnie aby jego eksploatacja nie przysparzała przedsiębiorstwu nadmiernych kosztów? W praktyce, w tym względzie, zbyt często preferuje się kryterium kosztowe, przyjmując rozwiązania najtańsze, gdyż nakłady na controlling są traktowane przez właścicieli małych firm na równi z ich prywatnymi wydatkami. W artykule starano się zaprezentować podstawowe przyczyny stosowania controllingu w małych przedsiębiorstwach oraz przedstawić metodykę konstruowania tej koncepcji dla tego rodzaju przedsiębiorstw, wychodząc z przedstawionych przesłanek, a przede wszystkim przeświadczenia braku wiedzy na ten temat wśród przedsiębiorców prowadzących małe firmy, utrudniającego racjonalny sposób postępowania.

\section{ISTOTA I PRZYCZYNY ZASTOSOWANIA CONTROLLINGU W MALYCH PRZEDSIĘBIORSTWACH}

Istotę controllingu, odpowiednią dla specyfiki małego przedsiębiorstwa, najogólniej sprowadzić można do wspomagania zarządzania, poprzez dostarczanie właścicielowi i pracownikom (menedżerom) informacji, jak i metod, które pozwolą lepiej podejmować decyzje, zarówno na strategicznym, jak i operacyjnym poziomie zarządzania. Zbierane, przetwarzane, gromadzone i analizowane informacje, ważne dla przedsiębiorstwa, mają wspierać poszczególne funkcje zarządzania, a szczególnie planowanie i kontrolę. Mogą one przybierać formę prostych danych liczbowych, ale też odpowiednio przygotowanych raportów, sprawozdań, adresowanych do określonych decydentów. Wobec dość częstego utożsamiania controllingu z kontrolą, należy stwierdzić, że controlling stosuje aktywną formę kontrolowania, która w większym stopniu służy zapobieganiu występowania negatywnych zjawisk (ex ante), aniżeli reagowaniu po fakcie (ex post). Możliwe odchylenia od zaplanowanych wielkości (zadań, norm) powinny być wykrywane najwcześniej jak to możliwe, jeszcze przed ich wystąpieniem, a podejmowane działania zaradcze mają zapobiegać niekorzystnym dla firmy konsekwencjom. Funkcja koordynacyjna, istotnie ważna w wypadku controllingu średnich i dużych przedsiębiorstw, nie ma w zasadzie zastosowania w małej firmie, ze względu przede wszystkim na jej małą złożoność organiza- 
cyjną. Poprawnie wprowadzony controlling może zapewnić małej firmie skuteczne jej funkcjonowanie na rynku (sfera operacyjna) i jednocześnie zagwarantować długofalowy rozwój (sfera strategiczna zarządzania).

Należy zauważyć, że dość powszechnie controlling traktuje się jako koncepcję właściwą dla dużych i średnich przedsiębiorstw (szczególnie w ich górnym przedziale wielkości), natomiast jej stosowanie w małych, a szczególnie mikro firmach uznaje się za zbyteczne. Uważa się bowiem, że zarządzanie małymi przedsiębiorstwami jest na tyle proste, że nie wymaga specjalistycznego wsparcia $\mathrm{w}$ metody i informacje. Tymczasem zasadnicze przyczyny wprowadzania controllingu do małych przedsiębiorstw są w swej istocie podobne do tych, które dotyczą dużych przedsiębiorstw ${ }^{3}$. Ogólną przyczyną korzystania z koncepcji controllingowego zarządzania jest potrzeba zapewnienia przedsiębiorstwu zdolności do przetrwania i rozwoju, w ciągle i dynamicznie zmieniającym się, trudno przewidywalnym i burzliwym otoczeniu. Rozwój przedsiębiorstwa jest tu szczególną kategorią. Małe przedsiębiorstwa są bowiem często zalążkiem średniego i wielkiego biznesu. Jest to istotnie ważne także z tego powodu, że małe firmy w większości upadają po krótkim okresie (1-2 lata) ich funkcjonowania. Ponadto za wprowadzeniem controllingu w małej firmie przemawia konieczność jak najlepszego wykorzystania z natury ograniczonych zasobów rzeczowych, finansowych i osobowych, dla realizacji przyjętych celów (poprawa efektywności gospodarowania zasobami). Niegospodarne ich traktowanie, $\mathrm{m}$. in. w wyniku nieprzygotowanych decyzji właściciela (przedsiębiorcy), może prowadzić nawet do upadłości przedsiębiorstwa i zagrożenia utraty podstawowego źródła jego dochodów. Dlatego też pożądane jest wszechstronne przygotowanie informacyjno-metodyczne decyzji (,dobre” planowanie), szczególnie o strategicznym znaczeniu dla małego przedsiębiorstwa, a następnie kontrolowanie stopnia wykonania planów (celów, zadań) i podejmowanie działań zaradczych, gdy wystąpią zagrożenia ich realizacji. W praktyce najczęstszymi przyczynami wprowadzenia controllingu w małej firmie jest potrzeba ,panowania” nad kosztami, określenie rentowności produktów, usług, potrzeba pełnej informacji o działalności i otoczeniu przedsiębiorstwa ${ }^{4}$. W małych przedsiębiorstwach niemieckich, austriackich i szwajcarskich ${ }^{5}$ ta koncepcja zarządzania

${ }^{3}$ Szerzej na temat przyczyn zob. S. Now o si els ki, Celowość wprowadzania controllingu w matej firmie, Prace naukowe Akademii Ekonomicznej we Wrocławiu Nr 1104, Wrocław 2006, s. $359 \mathrm{i} \mathrm{n.}$

${ }^{4} \mathrm{~W}$ odniesieniu do otoczeniu przedsiębiorstwa na znaczeniu zyskuje tzw. controlling komunikacyjny przedsiębiorstwa. Zdaniem J. Duraja odnosi się on do wszelakiego rodzaju nawiązywania, realizowania i rozwoju stosunków przedsiębiorstwa z otoczeniem. Chodzi tu nie tylko o wymianę informacji, ale także produktów, uczuć, praw własności, czy też wymianę myśli. Sprzyja to wzrostowi wartości rynkowej i społecznej firmy. Zob. J. D u raj, O istocie controllingu komunikacyjnego przedsiębiorstwa, [w:] J. Duraj (red.), Controlling $w$ zarzqdzaniu przedsiębiorstwem, Wydawnictwo Uniwersytetu Łódzkiego, Łódz-Spała 2001, s. 41 i n.

${ }^{5}$ Zob. m. in. R. Hofme ister, H. S ti e gle r, Controlling. Gestaltung und Anwendung für Klein- und Mittelbetriebe, 3. Aufl. Linz 1990; A. Kośmider, Controlling im Mittelstand: Eine 
znajduje coraz szersze zastosowanie. W polskich przedsiębiorstwach, jak wynika to $\mathrm{z}$ badań własnych, istnienie $\mathrm{w}$ firmie rozwiązań controllingowych potwierdza około $33 \%$ badanych małych firm, a na potrzebę wspomagania procesu decyzyjnego właścicieli i kierownictwa wskazuje przeciętnie $80 \%$ firm małych i średnich ${ }^{6}$.

\section{PREZENTACJA ZASAD I METODYKI WPROWADZANIA CONTROLLINGU}

Małe przedsiębiorstwa nie tylko przejawiają zainteresowanie controllingiem, ale także deklarują jego stosowanie. Czym się kierują, wybierając tą właśnie koncepcję zarządzania? Poszukiwanie odpowiedzi na pytanie o celowość stosowania koncepcji controllingu w małej firmie uznać zatem należy za podstawowy wybór o charakterze strategicznym, bardzo ważny zarówno z praktycznego, jak i poznawczego punktu widzenia. Kwestie te nie podlegaja zbyt często, jak dotychczas naukowej dyskusji, wskutek czego implementacje tej koncepcji mają często charakter intuicyjny, przypadkowy, mało skuteczny i nieefektywny. Chodzi zatem o to, aby wyboru tej koncepcji zarządzania nie pozostawiać przypadkowi czy modzie, a z pełną świadomością skutków takiej decyzji, biorąc pod uwagę potrzeby, możliwości i warunki funkcjonowania małej firmy, umieć odpowiedzieć na pytanie: czy i dlaczego należy wprowadzić controlling do małej firmy i co chce się osiagnąć, dzięki controllingowi? Pełną listę czynności związanych z wprowadzaniem controllingu ${ }^{7}$ przedstawiono na rys.1.

W pierwszej kolejności należy uzasadnić wybór koncepcji controllingowej dla małego przedsiębiorstwa. Najpierw dobrze jest zidentyfikować możliwe alternatywy dla controllingowej koncepcji (metody) zarządzania. Oznacza to, zgodnie z zasadą ekwifinalności, że konieczne staje się wzięcie pod uwagę innych, w stosunku do controllingu koncepcji i metod zarządzania, umożliwiających realizację postawionych celów (problemów). Na wybór i kształt controllingu wywierają wpływ przede wszystkim warunki wewnętrzne w danej firmie.

Untersuchung der Gestaltung und Anwendung des Controlling im mittelstaendischen Industrieunternehmen, 2. Auflage, Stuttgart 1994; R. Lan z, Controlling in kleinen und mittleren Unternehmen, 3. Auflage, Bern-Stuttgart 1992; P. R. Pre i s s le r, Controlling auch im Klein- und Mittelbetrieb, 9. Auflage, Eschborn 1994.

${ }^{6}$ Badania zostały wykonane w ramach grantu KBN nt. Controllingowa koncepcja zarzadzania małymi i średnimi przedsiębiorstwami, w 2003 r. przez zespół pracowników Akademii Ekonomicznej we Wrocławiu, pod kierownictwem S. Nowosielskiego, na losowej próbce badawczej liczącej 78 przedsiębiorstw, zaliczanych do sektora małych i średnich.

${ }^{7}$ Szczegółowy opis postępowania przedstawiono w opracowaniu: S. Now o siels ki, Controllingowa koncepcja zarzqdzania, [w:] K. S a fi in (red.), Zarzadzanie matym i średnim przedsiębiorstwem ,wyd. 2 popr. i uzup., Wydawnictwo Uniwersytetu Ekonomicznego we Wrocławiu, Wrocław 2012, s. 237-251. 


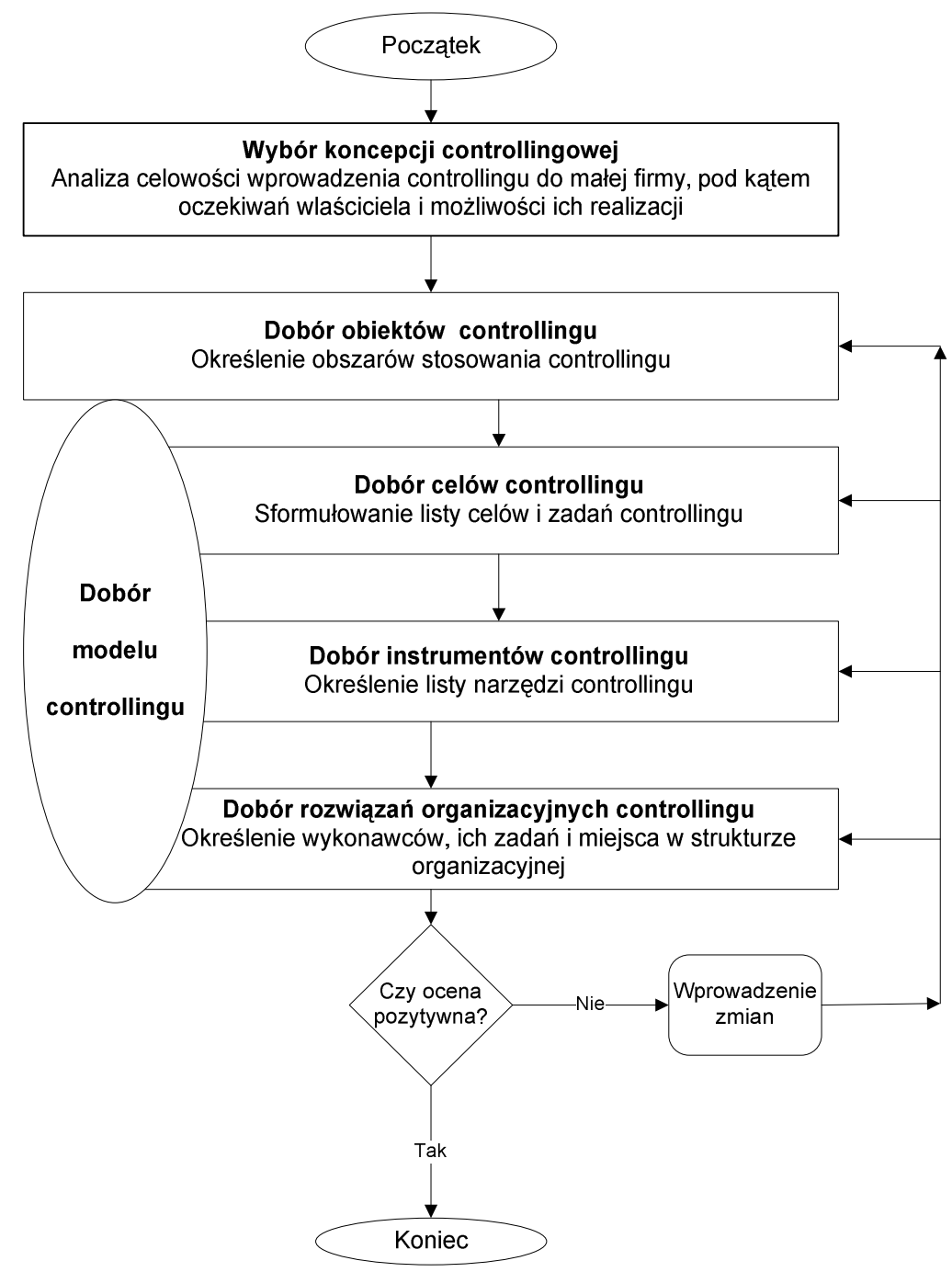

Rys.1. Przebieg czynności związanych z wyborem i operacjonalizacją koncepcji controllingowej zarządzania małym przedsiębiorstwem

Źródło: opracowanie własne.

W pierwszej kolejności należy wskazać na samego właściciela, jego cechy przedsiębiorcze, ale także cechy (zdolności) kierownicze i przywódcze, co kształtuje tzw. typ (profil) przedsiębiorcy. Największe zapotrzebowanie na czynności controlingowe wykazuje przedsiębiorca pionier - dynamiczny, kreatywny, ukierunkowany na zmiany, ale słabszy w talentach administracyjno- 
-kierowniczych (kontrolnych). Z kolei najmniej zainteresowany controllingiem jest przedsiębiorca rutyniarz - przeciwieństwo pioniera, z małymi skłonnościami do wprowadzania zmian, umiejący przeżyć tylko w statycznym środowisku, o słabych talentach kierowniczych. Wybierając i kształtując system controllingu należy brać pod uwagę różne aspekty organizacji wewnętrznej, w tym m. in.: poziom standaryzacji, formalizacji i centralizacji organizacji, profesjonalizm (kompetencje) pracowników, a także poziom kultury organizacyjnej.

Istotny jest również stan wiedzy na temat zarządzania i controllingu oraz doświadczenia z tym związane ${ }^{8}$. Ważna jest wielkość przedsiębiorstwa: inaczej należy widzieć controlling w mikrofirmie, a inaczej w małej firmie. Ważne są także cele (strategiczne i operacyjne) przyjęte w przedsiębiorstwie.

Z kolei wśród warunków zewnętrznych wpływających na kształt controllingu należy wymienić w szczególności: rodzaj i poziom stabilności otoczenia, ograniczony dostęp do zasobów przy jednoczesnym wzroście złożoności i różnorodności oferowanych produktów, wzrost konkurencyjności działania, co ma wpływ na rodzaj, złożoność i dynamikę zadań rynkowych. Bardzo istotnym czynnikiem, związanym z celami przedsiębiorstwa, jest specyfika i złożoność problemów oczekujących na rozwiązanie w konkretnej firmie. Mogą to być problemy natury ekonomicznej o charakterze strategicznym, takie np. jak zagrożenia związane z utratą rynków zbytu, czy też operacyjnym, jak np. długotrwałe trudności z utrzymaniem płynności finansowej, nadmierne zapasy czy zbyt wysokie koszty wytwarzania produktów ${ }^{9}$. Wskazać należy także na problemy natury organizacyjnej, takie jak: wąskie gardła, braki i zakłócenia w istniejącej organizacji i zarządzaniu, znacznie utrudniające funkcjonowanie firmy (np. trudności, czy brak umiejętności planowania sprzedaży, produkcji, kosztów, problemy w komunikowaniu się z pracownikami i otoczeniem firmy). Problemy te stanowią motywy, którymi może się kierować właściciel firmy, decydując się na wprowadzenie controllingu.

W celu dokonania właściwego wyboru, a konkretnie stwierdzenia zasadności zastosowania controllingu w małej firmie, można posłużyć się dwoma rodzajami kryteriów: tzw. atrakcyjności zarządzania oraz posiadanych kompetencji i zasobów firmy dla potrzeb zarządzania. Określenie atrakcyjności (wagi) zarządzania wymaga znalezienia odpowiedzi na pytanie o strategiczne jego znaczenie dla funkcjonowania małej firmy: czy lepsze zarządzanie (właśnie dzięki wsparciu controllingowemu), może pomóc w rozwiązywaniu bieżących, już zidentyfi-

${ }^{8} \mathrm{H}$. B ło c h, Bariery rozwoju controllingu w polskich przedsiębiorstwach, [w:] Controlling. Technologia zarzadzania firma, Profit, Katowice 2000, s. 93 i n.; C. S te inle, H. B r u ch i in., Controlling. Kompedium für Controller/innen und ihre Ausbildung, Schäffer-Poeschel Verlag, Stuttgart 1998, s. 32; M. Sierpińska, B. Niedbała, System controllingu operacyjnego w przedsiębiorstwie, Akademia Ekonomiczna w Krakowie 2000, s. 40 i n.

${ }^{9}$ Kluczowe problemy w poszczególnych fazach wzrostu firmy przedstawiono [w:] F. B ła w at (red.), Przetrwanie i rozwój matych i średnich przedsiębiorstw, Scientific Publishing Group, Gdańsk 2004, s. 80 i n. 
kowanych i przyszłych, jeszcze nieznanych problemów? Jeśli w wyniku analizy okaże się, że atrakcyjność zarządzania (jego przydatność dla realizacji postawionych celów) jest niska, to nawet przy posiadanych wysokich kompetencjach i dysponowanych zasobach (kadrowych, finansowych, informacyjnych), które mogłyby zostać spożytkowane dla potrzeb zarządzania, nie istnieją przesłanki do wprowadzenia controllingu w takiej firmie, w żadnej formie. Natomiast wysoka atrakcyjność zarządzania, przy małych kompetencjach i skromnych zasobach własnych sprzyja korzystaniu z doradztwa zewnętrznego, jako formy alternatywnej. Z kolei, w sytuacji dużej atrakcyjności zarządzania i bardzo wysokich kompetencji oraz mocnych zasobów, controlling stanowi najbardziej pożądaną funkcję wspomagającą zarządzanie małą firmą. W takim wypadku znajduje uzasadnione zastosowanie różnych - wewnętrznych i zewnętrznych - form wspomagania zarządzania małą firmą. Jak z tego widać, alternatywą controllingu wewnętrznego szczególnie dla małych firm jest doradztwo zewnętrzne z zakresu zarządzania, a to ze względu na występujący w analizowanym typie przedsiębiorstw deficyt gruntownie wykształconej kadry kierowniczej. Korzystanie z usług doradztwa zewnętrznego (doradcy, firmy consultingowe, biura rachunkowe i organizacje wspomagające funkcjonowanie firm z sektora msp) nie jest jeszcze powszechne ${ }^{10}$. Jednocześnie sygnalizowane są bariery korzystania z tego typu wspierania zarządzania, wśród których na pierwszym miejscu wymienia się zbyt wysokie koszty korzystania $\mathrm{z}$ doradztwa, relatywnie niskie kompetencje doradzających, czy też obawę przed wyniesieniem przez nich wiedzy o przedsiębiorstwie na zewnątrz firmy.

Dobór obiektów controllingu jest kolejną czynnością w organizowaniu controllingu w małej firmie. Należy wskazać obszary przedsiębiorstwa, w których ma on działać. Controllingiem nie można (choćby ze względów na znaczną pracochłonność jego późniejszej obsługi) i nie ma potrzeby obejmować (przynajmniej od razu) całego przedsiębiorstwa, choć w przypadku małego przedsiębiorstwa jest to możliwe. Należy wskazać i wybrać przede wszystkim te obszary (funkcje, procesy), które mają (lub będą miały w przyszłości), kluczowe znaczenie dla sukcesu przedsiębiorstwa. Chodzi tu o kompetencje, zasoby i atuty, jakich przedsiębiorstwo potrzebuje, aby w danej dziedzinie odnosić sukcesy (tzw. „źródła przewagi konkurencyjnej”). Proces wyboru można wzbogacić o szczegółową analizę kosztów, ale należy pamiętać, że podejście (kryterium) kosztowe wyboru, może być mylące. Nie w każdym bowiem przypadku obszary (funkcje, procesy) najbardziej kosztowne obecnie są najważniejsze ze strategicznego punktu widzenia ${ }^{11}$. Z własnych badań wynika, że znaczna część ankietowanych

${ }^{10} \mathrm{Z}$ badań prowadzonych w SGH wynika, że krajowe małe przedsiębiorstwa rzadko sięgają po zewnętrznych specjalistów. Zob. M. Strużycki (red.), Zarzadzanie matym i średnim przedsiębiorstwem. Uwarunkowania europejskie, Difin, Warszawa 200, s.158, 165. Z obserwacji własnych wynika ponadto, że biura rachunkowe, dysponując określonym potencjałem doradztwa w zakresie zarządzania małą firmą, nie są zbyt często proszone o świadczenie tego typu usług.

${ }^{11}$ Zwraca na to uwagę S tr a te g o r, Zarzqdzanie firmq, PWE, Warszawa 1997, s. 66. 
przedsiębiorstw wskazuje na częste trudności, związane z zarządzaniem obszarami sprzedaży (głównie w firmach produkcyjnych i handlowych), kosztów i finansów (przede wszystkim w firmach transportowych, usługowych i handlowych), czy działalności podstawowej (ma to miejsce głównie w budownictwie i produkcji).

Controlling można wprowadzić jednorazowo, co oznacza jednoczesne „,nałożenie" controlingu na wszystkie wytypowane obszary, a co nie jest proste, ze względu na okresowe znaczne zaangażowanie zasobów. Można też wprowadzać controlling stopniowo, rozpoczynając od jednego z wybranych obszarów i konkretnej koncepcji (metody) zarządzania, np. budżetowania, stanowiącej określoną funkcję controllingu. Po jakimś czasie można objąć controllingiem wszystkie pozostałe obszary funkcjonalne i jednostki organizacyjne przedsiębiorstwa. Pozyskane doświadczenia w jednym obszarze (jednostce) można szybko przenieść do innych obszarów. Controlling może być stosowany również przy realizacji wyodrębnionych projektów i procesów. W małej firmie istnieje bowiem możliwość wydzielenia centrów odpowiedzialności na bazie oddzielnie realizowanych projektów, a w przypadku procesów, jest możliwe jego osadzenie na podstawowym makroprocesie, jakim jest realizacja zamówienia klienta.

W kolejnym kroku następuje dobór modelu controllingu, który będzie „obsługiwał” wybrane obszary. W tym celu trzeba określić cele, narzędzia i rozwiązania organizacyjne, właściwe dla określonej sytuacji, co stanowi zasadniczy element modelu controllingu. Zarządzający przedsiębiorstwem również w tym zakresie mają możliwości wyboru, które zależą m. in. od: profilu przedsiębiorcy, celów przedsiębiorstwa, rodzaju i treści oczekiwanych usług w zakresie wsparcia zarządzania, kwalifikacji i „mocy przerobowych” pracowników, dotychczasowego poziom rozwoju systemu controllingu ${ }^{12}$. Wyboru modelu controllingu dla danego przedsiębiorstwa, można dokonać spośród czterech modeli, opracowanych $\mathrm{w}$ oparciu o rozwiązania prezentowane $\mathrm{w}$ literaturze przedmio$\mathrm{tu}^{13}$. Należą do nich:

1) controlling zorientowany na informacyjne zabezpieczenie wybranych funkcji,

2) controlling zorientowany rachunkowo,

3) controlling zorientowany na problemy operacyjne,

4) controlling zorientowany na problemy strategiczno-operacyjne (zintegrowany) $)^{14}$.

${ }^{12}$ C. Steinle, H. Bruch i in., op. cit., s. 31.

${ }^{13}$ Zob. m. in. R. Es chen b a ch (Hrsg), Controlling, 2. Auflage, Schaeffer-Poeschel Verlag, Stuttgart 1996, s. 161-167; B. A m s h off, Controlling in deutschen Unternehmungen. Realtypen, Kontext und Effizienz, 2. Auflage. Gabler, Wiesbaden 1993, s. 129-131; C. S te in le, H. B r u ch i i n., op. cit., s. 7-9.

${ }^{14} \mathrm{~J}$. Li cht ar ski, S. Now o si els ki, Modele controllingu dla matych i średnich przedsiębiorstw, „Organizacja i Kierowanie” 2005, nr 2, s. 3-15. 
Modele te zostały uporządkowane według stopnia ich rozwoju (zob. rys. 2), a syntetyczna charakterystyka wymienionych modeli controllingu została zaprezentowana w tab. 1.

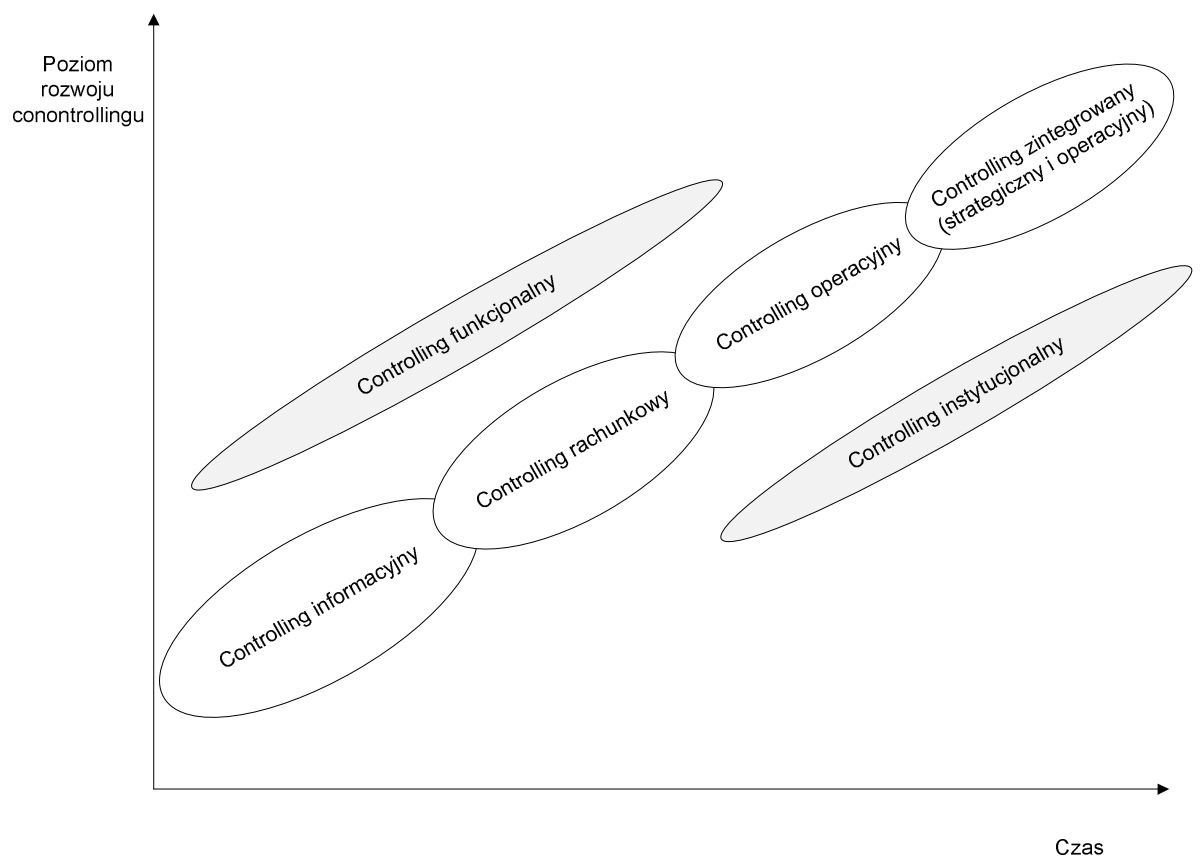

Rys. 2. Fazy rozwoju controllingu w małym przedsiębiorstwie

Źródło: jak do rys. 1.

Poszukując rozwiązań dla konkretnej firmy należy mieć świadomość istnienia wielu różnych form (modeli) controllingu, a zatem konieczności wyboru jednej z wielu ścieżek prowadzących do jego wprowadzenia. Wybór taki nie jest przesądzony z góry i powinien zostać podporządkowany określonym kryteriom. Należy jednak stwierdzić, że nie istnieje jeden, na tyle ogólny model (typ) controllingu dla tej klasy przedsiębiorstw, aby każdy właściciel (menedżer) mógł go wykorzystać w praktyce. Ponadto, jak to wynika z doświadczeń przedsiębiorstw wprowadzających taką koncepcję, najbardziej uzasadniona jest ścieżka rozwoju controllingu, począwszy od controllingu zorientowanego na informacyjne zabezpieczenie wybranych funkcji, poprzez controlling rachunkowy i operacyjny, aż do controllingu zintegrowanego. Każdy kolejny, ,,wyższy” model controllingu zawiera w sobie rozwiązania stosowane wcześniej, przez „niżej” rozwinięty model controllingu. 
Modele controllingu właściwe dla małych firm

\begin{tabular}{|c|c|c|c|c|}
\hline & $\begin{array}{c}\text { Controlling } \\
\text { informacyjny }\end{array}$ & $\begin{array}{l}\text { Controlling } \\
\text { rachunkowy }\end{array}$ & $\begin{array}{l}\text { Controlling } \\
\text { operacyjny }\end{array}$ & $\begin{array}{c}\text { Controlling } \\
\text { zintegrowany }\end{array}$ \\
\hline $\begin{array}{l}\text { Przezna- } \\
\text { czenie } \\
\text { (cele) }\end{array}$ & \begin{tabular}{||} 
Pozyskiwanie in- \\
formacji (m. in. \\
poprzez sporzą- \\
dzanie analiz, ra- \\
portów), pomoc- \\
nych w podejmo- \\
waniu decyzji, \\
z reguły o charak- \\
terze bieżącym.
\end{tabular} & $\begin{array}{l}\text { Kontrola podstawo- } \\
\text { wych wielkości } \\
\text { ekonomicznych } \\
\text { przedsiębiorstwa } \\
\text { (przychodów, } \\
\text { kosztów) oraz ren- } \\
\text { towności i płyn- } \\
\text { ności finansowej. }\end{array}$ & \begin{tabular}{|l} 
Kreuje i wspiera \\
planowanie (bu- \\
dżetowanie). Są \\
wyodrębnione \\
centra odpowie- \\
dzialności, które \\
podlegają okre- \\
sowej kontroli, \\
(analiza odchy- \\
leń i propozycje \\
zmian). \\
\end{tabular} & $\begin{array}{l}\text { Wspomaga strate- } \\
\text { giczny i opera- } \\
\text { cyjny szczebel } \\
\text { zarządzania, } \\
\text { w zakresie } \\
\text { funkcjonalnym, } \\
\text { instrumental- } \\
\text { nym i instytu- } \\
\text { cjonalnym. }\end{array}$ \\
\hline Narzędzia & $\begin{array}{l}\text { Nieskomplikowane, } \\
\text { o małym stopniu } \\
\text { formalizacji. }\end{array}$ & $\begin{array}{c}\text { Tradycyjny (ex post) } \\
\text { rachunek kosztów, } \\
\text { ewentualnie ra- } \\
\text { chunek kosztów } \\
\text { planowanych. }\end{array}$ & $\begin{array}{l}\text { Sformalizowane } \\
\text { procedury pla- } \\
\text { nowania (budże- } \\
\text { towania) i kon- } \\
\text { trolowania, cen- } \\
\text { tra odpowie- } \\
\text { dzialności, roz- } \\
\text { budowany sys- } \\
\text { tem informacyj- } \\
\text { ny. }\end{array}$ & $\begin{array}{l}\text { Pełna ,skrzynka } \\
\text { narzędziowa” } \\
\text { controllera, po- } \\
\text { siada rozwinięty } \\
\text { system informa- } \\
\text { cyjny i informa- } \\
\text { tyczny. }\end{array}$ \\
\hline Organizacja & $\begin{array}{l}\text { Charakter funkcjo- } \\
\text { nalny (nieinstytu- } \\
\text { cjonalny), z reguly } \\
\text { nie korzysta z do- } \\
\text { radztwa zewnętrz- } \\
\text { nego. }\end{array}$ & $\begin{array}{c}\text { Charakter funkcjo- } \\
\text { nalny (zadania } \\
\text { controllingu są } \\
\text { rozproszone mię- } \\
\text { dzy istniejące już } \\
\text { stanowiska). Róż- } \\
\text { ne formy doradz- } \\
\text { twa zewnętrznego. }\end{array}$ & $\begin{array}{l}\text { Charakter funkcjo- } \\
\text { nalny lub insty- } \\
\text { tucjonalny, } \\
\text { a także wyko- } \\
\text { rzystuje różne } \\
\text { formy doradztwa } \\
\text { zewnętrznego. }\end{array}$ & $\begin{array}{l}\text { Przyjmuje najczę- } \\
\text { ściej formę in- } \\
\text { stytucjonalną } \\
\text { (wyodrębniony } \\
\text { dział). }\end{array}$ \\
\hline Zastosowanie & \begin{tabular}{|l} 
Szczególnie w fir- \\
mach mikro, ale \\
też małych, \\
o „,skromnym” \\
personelu - pod \\
względem stanu \\
i kwalifikacji - \\
personelu. Począt- \\
kowa faza rozwo- \\
ju firmy.
\end{tabular} & $\begin{array}{l}\text { Szczególnie w ma- } \\
\text { łych (ale także } \\
\text { mikro) firmach, } \\
\text { dysponujących } \\
\text { wykwalifikowa- } \\
\text { nymi służbami } \\
\text { finansowo- } \\
\text {-księgowymi. }\end{array}$ & \begin{tabular}{|l} 
Szczególnie \\
w firmach śred- \\
niej wielkości, \\
ale także firmach \\
małych, prze- \\
ważnie w gór- \\
nym przedziale \\
ich wielkości.
\end{tabular} & $\begin{array}{l}\text { Charakterystyczny } \\
\text { dla firm dużych, } \\
\text { ale może mieć } \\
\text { miejsce w śred- } \\
\text { nich firmach, } \\
\text { a nawet w małej } \\
\text { firmie, szcze- } \\
\text { gólnie w jej } \\
\text { górnym prze- } \\
\text { dziale wielkości. }\end{array}$ \\
\hline
\end{tabular}

Źródło: opracowanie własne.

Controlling w małych przedsiębiorstwach nie musi w każdym wypadku „,rozwijać” się aż do poziomu najwyższego. Na pewno swą drogę ku doskonało- 
ści powinien rozpoczynać od controllingu informacyjnego, poszerzając stopniowo swój zakres przedmiotowy o kolejne, nie koniecznie wszystkie elementy „wyższych” modeli, przechodząc również z czasem od controllingu funkcjonalnego do controllingu instytucjonalnego.

W kolejnym etapie następuje dobór celów controllingu. Ten etap należy uznać za szczególnie ważny dla skutecznego funkcjonowania controllingu w małej firmie. Cele controllingu można wyprowadzać wprost z celów przedsiębiorstwa, co nie jest łatwe, szczególnie w sytuacji gdy mała firma pracuje bez formalnie określonych celów. Jednak takie klasyczne cele przedsiębiorstwa jak zysk, rentowność, sprzedaż, udział w rynku nie dają właściwych podstaw dla określania celów controllingu. Ustalając cele, można też orientować się na problemy, utrudniające funkcjonowanie firmy. Cele stawiane controllingowi w praktyce przedsiębiorstw przybierają różną treść, np. zapewnienie szybszej reakcji na zmiany rynkowe, eliminacja zaskoczeń, ale także bardziej konkretne, jak np. obniżanie kosztów, zwiększanie przychodów, poprawa płynności finansowej przedsiębiorstwa. W każdym wypadku cele muszą być zoperacjonalizowane, a samo formułowanie i uszczegóławianie celów wskazuje oczekiwania stawiane przez przedsiębiorcę (właściciela) przed controllingiem i uzasadnia (legitymizuje) sens jego funkcjonowania.

Wydaje się, że w wypadku małych przedsiębiorstw można wyodrębnić następujące cele controllingu, o charakterze formalnym:

- zapewnienie informacji pod potrzeby decyzyjne,

- wspieranie funkcji kontroli,

- kreowanie funkcji planowania i prowadzenie praca planistycznych,

- prowadzenie analizy odchyleń i przygotowywanie propozycji działań regulacyjnych,

- inspirowanie właściciela do wprowadzania zmian w obszarze zarządzania i zajmowanie się wdrażaniem koncepcji i metod zarządzania lub usprawnianiem już stosowanych narzędzi (inicjowanie prac modyfikujących obecnie stosowane rozwiązania, poprawa jakości i skrócenie czasu procesu decyzyjnego, bez uszczerbku dla przedsiębiorczej intuicji i elastyczności) ${ }^{15}$.

Przedstawiona lista celów nie wyczerpuje wszystkich możliwości i w przypadku konkretnego przedsiębiorstwa trzeba ją odpowiednio kształtować. Ponadto wymienione cele mają charakter stopniowalny: nabierają one treści (,,rozwijają się") wraz z przechodzeniem na wyższy poziom rozwoju controllingu. Zasadne jest dobieranie określonych celów, do konkretnej sytuacji przedsiębiorstwa, z wykorzystaniem sformułowanych wcześniej kryteriów wyboru, a następnie operacjonalizowanie ich. Gdy za cel controllingu zostanie przyjęte ,zapewnienie informacji pod potrzeby decyzyjne" można go uszczegółowić poprzez następujące zadania:

${ }^{15}$ Opracowano w oparciu o szeroką listę celów przedstawionych w pozycji: B. A m sh off, op. cit., s. 180-207. 
- kreowanie popytu na informacje ze strony właściciela i zarządzających mała firmą,

- systematyczne pozyskiwanie i przekazywanie potrzebnych informacji,

- zagwarantowanie sprawnego przepływu informacji między poszczególnymi stanowiskami w firmie (obieg dokumentacji),

- dobór i wprowadzenie informatycznych technologii informacyjno-komunikacyjnych.

W wypadku wyboru celu „wspieranie funkcji kontroli”, należy mieć świadomość różnych co do pracochłonności form takiej kontroli. Mogą to być relatywnie proste czynności (np. zwykłe, ręczne zestawienie wielkości planistycznych z rzeczywistymi i pobieżna ocena stanu rozbieżności), ale też bardzo pracochłonne prace (rozbudowana analiza porównawcza w czasie i przestrzeni, szczegółowa analiza odchyleń, z wykorzystaniem specjalistycznego oprogramowania komputerowego). Zaleca się stosować selektywny wybór przedmiotów kontroli, ograniczając się (na początku) do podstawowych, „żywotnych” dla małej firmy wielkości ekonomicznych, jako przedmiotu kontroli.

W kolejnym kroku należy dokonać doboru instrumentów controllingu. Rodzaj (wybór) stosowanych instrumentów zależy od przyjętego w konkretnym przedsiębiorstwie modelu controllingu, wyodrębnionych obszarów funkcjonowania controllingu, kwalifikacji personelu i poziomu percepcji wyników obliczeń, stosowanej techniki obliczeniowej i posiadanego oprogramowania, a także ilości i złożoności problemów decyzyjnych. Najogólniej instrumenty controllingu dotyczą zarządzania strategicznego oraz operacyjnego. Można je podzielić na: systemy oraz metody ${ }^{16}$. Systemy stanowią kompleksy narzędzi, złożone $\mathrm{z}$ wielu powiązanych ze sobą części, obejmujące wiele lub wszystkie fazy podstawowych funkcji planowania i kontroli. Zalicza się do nich: systemy rachunku kosztów, systemy planowania i kontroli inwestycji, system informacyjny, system wskaźników, centra kosztów i centra zysku. Do technicznej obsługi tych kompleksów narzędzi niezbędne jest zarówno oprogramowanie jak i odpowiedni sprzęt komputerowy. Z kolei metody stanowią indywidualne narzędzia, stosowane $\mathrm{w}$ różnych obszarach zadaniowych $\mathrm{w}$ ramach planowania, kontroli i sterowania, które są często elementami systemów. Zalicza się tu m. in.: analizę cyklu życia, analizę ABC, analizę progu rentowności, symulację, analizę wrażliwości, metodę zdyskontowanych przepływów pieniężnych, analizę porównawczą, analizę ryzyka, techniki planowania sieciowego, wszystkie rodzaje analizy odchyleń, metodę budżetowania zerowego, rachunek kosztów celowych. Zastosowanie konkretnych narzędzi jest uwarunkowane spełnieniem szeregu warunków. W małych przedsiębiorstwach najważniejszym kryterium zastosowania określonych narzędzi jest umiejętność posługiwania się nimi przez właściciela i pracowników. Najogólniej wraz z przechodzeniem od niższych do wyższych modeli controllingu powstają warunki do stosowania większej liczby, bardziej złożo-

${ }^{16}$ Zob. C. Steinle, H. Bruch i in., op. cit., s. 379. 
nych instrumentów, wspieranych techniką komputerową, opartej o wspólną bazę danych i wykorzystującą interaktywne formy dialogu.

W końcu należy dobrać rozwiązania organizacyjne controllingu, czyli zdecydować kto będzie wykonawcą funkcji controllingowych. Rozwiązania organizacyjne w obszarze controllingu w małych firmach lokują się w przedziale od własnego stanowiska controllera do doradcy zewnętrznego. Ich przegląd przedstawiono w tab. 2 .

Tabela 2

Możliwe rozwiązania organizacyjne w małych przedsiębiorstwach

\begin{tabular}{|c|c|c|}
\cline { 2 - 3 } \multicolumn{1}{c|}{} & \multicolumn{1}{c|}{ Rozwiązanie organizacyjne } & \multicolumn{1}{c|}{ Objaśnienie } \\
\hline 1. & $\begin{array}{c}\text { Utworzenie stanowiska controllera } \\
\text { w firmie }\end{array}$ & $\begin{array}{c}\text { Controller jest wykonawcą funkcji i zadań } \\
\text { controllingu }\end{array}$ \\
\hline 2. & $\begin{array}{c}\text { Rozłożenie zadań controllingowych na } \\
\text { istniejące już stanowiska }\end{array}$ & $\begin{array}{c}\text { Funkcje controllingowe zostają rozłożone na } \\
\text { zadania szczegółowe i rozdzielone na już } \\
\text { istniejące stanowiska }\end{array}$ \\
\hline 3. & $\begin{array}{c}\text { Rozszerzenie zadań już funkcjonującego } \\
\text { controllera }\end{array}$ & $\begin{array}{c}\text { Controllerowi przydziela się dodatkowe } \\
\text { zadania, które wykonuje on obok swoich } \\
\text { obecnych zadań }\end{array}$ \\
\hline 4. & $\begin{array}{c}\text { Wspólny controller dla wielu przedsię- } \\
\text { biorstw }\end{array}$ & $\begin{array}{c}\text { Wiele przedsiębiorstw korzysta wspólnie } \\
\text { z jednego controllera }\end{array}$ \\
\hline 5. & $\begin{array}{c}\text { Przejęcie zadań controllingowych przez } \\
\text { zewnętrznego doradcę }\end{array}$ & $\begin{array}{c}\text { Funkcje i zadania controllingowe zostają } \\
\text {,wyprowadzone” poza przedsiębiorstwo }\end{array}$ \\
\hline
\end{tabular}

Źródło: R. Lan z, Controlling in kleinen und mittleren Unternehmen, 3. Auflage, BernStuttgart 1992, s. 321 i n., [za:] S. Nowo sielski, Formy organizacji controllingu w matych i średnich przedsiębiorstwach, [w:] Stan rozwoju i zakres stosowania controllingu operacyjnego w matych i średnich przedsiębiorstwach, PN AE we Wrocławiu nr 1101, WAE Wrocław 2006, s. 55.

Również w tej sytuacji decyzyjnej należy posiłkować się określonymi kryteriami. Między innymi istotna jest wielkość przedsiębiorstwa, ale też poziom obciążenia pracą istniejących stanowisk (komórek), wykonujących zbliżony do controllingowych zakres prac oraz gotowość do „przyjęcia” przez pracowników na tych stanowiskach dodatkowych zadań.

\section{UWAGI KOŃCOWE}

W świetle egzystencjalnych problemów jakie przeżywają małe firmy, kończących się bardzo często upadłością, stwierdzenie, że controlling jest zbyt drogim narzędziem, skomplikowanym i niepotrzebnym w takich firmach, jest co najmniej nieodpowiednie. Brak kontroli kosztów i płynności firmy, nadmierne zadłużanie się, przejadanie zysków i brak inwestycji, a z drugiej strony brak 
wizji rozwoju przedsiębiorstwa, mało ambitne cele i nieumiejętność zarządzania (błędy w zarządzaniu ), to tylko niektóre z przyczyn prowadzących do upadku małej firmy. Gdy jednocześnie właściciel małej firmy bierze na siebie większość obowiązków, czy to z powodów oszczędnościowych, czy też z przekonania, że nikt nie jest w stanie zrobić tego lepiej niż on, to takie zachowanie, nadmiernie absorbujące czas, przesłania konstruktywne myślenie i nie daje możliwości uzupełniania wiedzy menedżerskiej, a tym bardziej niezbędnej refleksji. Zarządzający małym przedsiębiorstwem musi mieć pełną świadomość tego, że warunkiem długotrwałego funkcjonowania jego firmy nie jest tylko „robienie” zysku, ale zapewnienie przedsiębiorstwu płynności finansowej, wynikającej z płynności sprzedaży, co powinno mieć najwyższy priorytet w jego funkcjonowaniu. Płynność i rentowność nie zawsze zmierzają w tym samym kierunku. Nawet rentowne małe przedsiębiorstwo, może przeżywać trudności płatnicze. Dlatego sterowanie płynnością finansową staje się naczelnym zadaniem nie tylko funkcji księgowej (rachunkowości finansowej), ale ze względu na wielość czynników z tym związanych powinna być także przedmiotem szczegółowych analiz controllingu. Podobnie jest z kosztami. Szczególnie małe przedsiębiorstwa muszą nierzadko redukować koszty szybko, drastycznie i często dramatycznie. Wskazywanie, w konkretnych warunkach, gdzie można obniżyć koszty natychmiast, bez większego wysiłku i bez poważniejszych konsekwencji dla przyszłości firmy, może i powinno być ważnym zadaniem controllingu.

W świetle przedstawionych rozważań, pozytywna decyzja o wprowadzaniu controllingu w małej firmie, w formie dostosowanej do jej potrzeb i możliwości, jest oczywista. Jednocześnie przenoszenie sprawdzonych rozwiązań z firm dużych do małych nie jest możliwe, a w każdym przypadku koncepcja i instrumenty controllingu muszą zostać dopasowane do specyfiki konkretnego małego przedsiębiorstwa i ambicji rozwojowych przedsiębiorcy. Wówczas też przedstawiona w artykule metodyka postępowania, prowadząca do zaimplementowania i poprawnego funkcjonowania rozwiązań controllingowych, zyskuje na praktycznym znaczeniu. W efekcie controlling staje się gwarancją bezpieczeństwa funkcjonowania bieżącego małej firmy i jej strategicznego rozwoju.

\section{BIBLIOGRAFIA}

Amshoff B., Controlling in deutschen Unternehmungen. Realtypen, Kontext und Effizienz, 2. Auflage, Gabler, Wiesbaden 1993.

B ł a w at F. (red.), Przetrwanie i rozwój małych i średnich przedsiębiorstw, Scientific Publishing Group, Gdańsk 2004.

B ło ch H., Bariery rozwoju controllingu w polskich przedsiębiorstwach, [w:] Controlling. Technologia zarzqdzania firma, Profit, Katowice 2000.

D u raj J., O istocie controllingu komunikacyjnego przedsiębiorstwa, [w:] J. Duraj (red.), Controlling $w$ zarzqdzaniu przedsiębiorstwem, Wydawnictwo Uniwersytetu Łódzkiego, Łódź-Spała 2001. 
E s chen bach R. (Hrsg), Controlling, 2. Auflage, Schaeffer-Poeschel Verlag, Stuttgart 1996.

Hofme ister R., S ti e gle r H., Controlling. Gestaltung und Anwendung für Klein- und Mittelbetriebe, 3. Auflage, Linz 1990.

Lichtarski J., Now os i elski S., Modele controllingu dla matych i średnich przedsiębiorstw, „Organizacja i Kierowanie” 2005, nr 2.

Kośmider A., Controlling im Mittelstand: Eine Untersuchung der Gestaltung und Anwendung des Controlling im mittelstaendischen Industrieunternehmen, 2. Auflage, Stuttgart 1994.

$\mathrm{Kunesch}$ H., Besonderheiten des Controlling in Klein- und Mittelbetrieben, [w:] R. E s che nb a ch (Hrsg.), Controlling, 2. Auflage, Stuttgart 1996.

L a $\mathrm{z}$ R., Controlling in kleinen und mittleren Unternehmen, 3. Auflage, Verlag Paul Haupt, Bern und Stuttgart 1992.

Mikołajczyk Z., Zimniewicz K., Zarzadzanie matym przedsiębiorstwem, [w:] B. Pias e c ki (red.), Ekonomika i zarzqdzanie mała firmq, PWN, Warszawa-Łódż 2001.

Nowosielski S., Celowość wprowadzania controllingu w małej firmie, Prace naukowe Akademii Ekonomicznej we Wrocławiu, Nr 1104/2006.

Now osielski S., Formy organizacji controllingu $w$ matych i średnich przedsiębiorstwach, [w:] Stan rozwoju i zakres stosowania controllingu operacyjnego w matych $i$ średnich przedsiębiorstwach, PN AE we Wrocławiu nr 1101, WAE, Wrocław 2006.

Nowosielski S., Controllingowa koncepcja zarzadzania, [w:] K. Safin (red.), Zarzadzanie matym i średnim przedsiębiorstwem, wyd. 2 popr. i uzup., Wydawnictwo Uniwersytetu Ekonomicznego we Wrocławiu, Wrocław 2012.

Pre is s le r P. R., Controlling auch im Klein- und Mittelbetrieb, 9. Aufl. Eschborn 1994.

Steinle C., Bruch H. i in., Controlling. Kompedium für Controller/innen und ihre Ausbildung, Schäffer-Poeschel Verlag, Stuttgart 1998.

S trat e g or, Zarzqdzanie firma, PWE, Warszawa 1997.

S tru ży cki M. (red.), Zarzqdzanie matym i średnim przedsiębiorstwem. Uwarunkowania europejskie, Difin, Warszawa 2002.

\section{Stanistaw Nowosielski}

\section{CONTROLLING CONCEPT OF SMALL BUSINESS MANAGEMENT. FUNDAMENTALS OF CONSTRUCTION}

The article firstly presents the essence and causes of using controlling in small business. Nextly it shows staged methodology of controlling concept constructing for these kinds of businesses. It is based on presented premises and conviction of lack on this subject knowledge among small business entrepreneurs. The article also describes next stages, bringing closer problems connected with strategic selection of controlling concept in small business, choice of structures, aims, tools and controlling organization.

Key words: controlling, goals, instruments, solutions. 